ain, and the influence exercised therein by John Hunter, by the French school, and lastly by that of Germany, Dr. Osler dwelt with admirable skill, which showed how thorough and wide are his sympathies and knowledge. Then he sketched in turn some of the characteristics of the medical art in each of the possessions of the Empire, and closed his stimulating and powerful address with words full of encouragement and hope. It may well be that in the time to come the greatest advances in medicine will be made in Greater Britain, and the centre of intellectual activity be shifted from the Motherland to her colonies The evidences we have in the magnificent universities of Canada would warrant such a prediction; and if that indeed is to be their destiny, none will rejoice more than the country from whose loins they sprang, as the parent rejoices in the achievements of his offspring. The field is open and the labourers are many. There is much, very much, yet to be gleaned by patient observation and research, and to our thinking not the least of the aims of the British Medical Association should be that which fosters and encourages the investigation of the problems of disease as met with in the countries to which her members belong.

Dr. Mitchell Banks, in his Address in Surgery, did well to recall attention to that branch of our profession which by some strange perversity on the part of those in authority is at the present time suffering unmerited neglect, and perchance his recital of the deeds done by some of the foremost army surgeons of olden time may have the effect of demonstrating the esteem in which these members of our profession should be held by those whose country they so nobly serve. The roll of the army medical service contains many names of men who have done deeds of heroism that have been written in history; but in every campaign all of these "non-combatants" play the part of heroes, in their -devotion to duty and unwearying efforts to mitigate the horrors of war and relieve the sufferings of its victims under circumstances of difficulty and danger. Of the address itself, it may be said that it unfolded to view much that was not only interesting, but also worthy to be recalled and recorded, and many who listened to it were doubtless first made acquainted with the lives of the men so happily sketched by the orator. Of more than antiquarian interest was the relation of the discovery of the monumental tablet at Housesteads in Northumberland which proves that the Roman cohorts were furnished with their surgeons, the record of this discovery being made by the late Sir James Simpson. The sketch given by Dr. Banks of the life of Ambroise Paré reminds us of the great services rendered by this pioneer in military surgerywhose original mind and independent spirit marks him out as one of surgery's masters, whose invention of the ligature entitles him, as Dr. Banks says, to rank side by side with the two great geniuses of modern times, he who discovered anæesthetics and he who introduced antiseptics. Robert Clowes, Peter Lowe, Woodall, and Richard Wiseman were each in turn described and their distinctive characteristics sketched in terms that brought these writers back to life, with their quaint receipts and shrewd British common sense exercised on many a battlefield. Little could they havedreamt that the lives and record of their labours would have been recited centuries after their day on a spot of which the existence was then unknown to their countrymen. To Baron Larrey, whose services to Napoleon in his campaigns earned from that stern heart a recognition he rarely bestowed, Dr. Banks devoted considerable attention, and with reason, for Larrey stands out foremost amongst this branch of our profession, and his experiences must have been wider and more varied than ever fell to the lot of the military surgeon. Finally, after a brief mention of some of the deeds done in modern times by our medical officers, Dr. Banks told his audience why be had selected this theme for his address, and, as we have said above, we trust that his recital of the services which army surgeons in all time have rendered to humanity will bear the fruit which he and we desire.

It seems to us that with this meeting at Montreal, memorable as it will be in many ways, the British Medical Association enters upon a new career. Those of its mem bers who are attending it from England will realise that in Greater Britain the medical profession is animated by the same spirit as at home; that with the common participa tion of membership of the same body there must be equally the common desire towards the same ends, the furtherance of the art and science of medicine for the sake of human. ity, the promotion of fellowship between those who pursue the same calling. More than this, it may be hoped that, as the Association expands, its sphere of work will widen, too, and that some of those objects rehearsed by Dr. Roddick as originally propounded by its founders will be extended to all the Empire. The subject matter of the President's address suggests, indeed, one line of useful work, which might well be undertaken, namely, the col. lation of records as to the climatic and physical conditions of the various countries in which the branches of the Asso. ciation exist, and the collective investigation of disease on a more ample scale than was originally contemplated by those earnest and enthusiastic advocates of this line of inquiry, the late Sir George Humphry and the late Dr. Mahomed. The Association has long ceased to be "provincial," it is now more than insular, and with its worldwide expansion must come the growth of new ideas, the emancipation from the fetters of narrow policies and the working together of the medical profession of the British Empire to attain all that is most worthy in the promotion of professional aims and to maintain a high standard of professional honour.

\section{(Opening Adduress}

BY

\section{T. G. RODDICK, M.D., M.P., President,} Professor of Surgery, McGill University.

You have been welcomed to the Dominion of Canada by the Noble Earl who is the worthy representative of our beloved Queen; you have been welcomed to the Province of Quebec, to which this city belongs, by our eloquent and justly-esteemed Lieutenant-Governor; the Chief Magistrate of our city has given you "Caed mille failthe" in a manner in which only an Irishman with such a great sympathetic heart as he possesses can give; and now I rise to welcome you on behalf of the medical pro. fession in Canada, and to thank you for the honour conferred on this city and country by your presence here to-day. Would that I could find suitable language in which to thank you also for the high honour you have done me in electing me to preside at this great meeting of the British Medical Association, an honour which is appreciated none the less by the consciousness that it is not a personal matter but a compliment to Canadian medicine.

This meeting of the British Medical Association in Canada is an event which will serve still more to impress upon the memory of our people the year 1897, the year of the Diamond Jubilee of our beloved Sovereign, Queen Victoria. In no part of her vast Empire-not even in it: very heart-did her subjects celebrate the great event with more enthusiastic loyalty and devotion than in Canada, especially in this province, the home of the French-Canadians. We Canadians of both tongues lore and honour our Queen. Long may she live! Deeply, too. have we appreciated here the splendid reception accorded in the old home to our Premier, the Right Hon. Sir Wilfrid Laurier, whose distinguished bearing and grace of manner 
eminently fitted him for the important part it was his peculiar privilege to play in the magnificent ceremonies of the Jubilee. A French-Canadian, Sir Wilfrid's presence in England as the chosen representative of the Dominion was an object lesson to the Empire and to the world in the harmony existing between the two nationalities which comprise the Canadian people.

And here let me express on behalf of every representative from the British Isles, and on behalf of every Canadian present, the genuine pleasure we feel in having among us on this memorable occasion so many of our brethren from the United States. This only proves the cosmopolitan character of our profession; this is only another recognition of the unity of medicine. Legislators may squabble, the air may be filled with wild alarms, and war may appear imminent day by day, but our relations are not disturbed in the slightest degree; our interests are common -we are kinsmen in science; we go forward hand in hand, irrespective of race or creed or colour, having one intent only : the advancement of our noble profession, and through that the amelioration of the ills of mankind.

It is my privilege also to welcome the representative of another Republic, La Belle France, to whose gifted men of science our profession is so greatly indebted. This gentleman, who bears the credentials of his Government, and officially represents the great nation of which he is so bright an ornament, is known far and wide as the Professor of Physiology in the University of France, Dr. Charles Richet. In coming to Canada it cannot be said, nor will he feel, that he comes to a foreign country, for in the Province of Quebec he will find another France, with a delightful mingling of the old and the new : his own beautiful language spoken with all the grace and purity of the old régime.

But we are further honoured by the presence among us to-day of the most illustrious surgeon of our generation, Lord Lister, who stands for the rise and zenith of modern surgery. It has been well and truly said that as long as surgery is scientifically discussed Lord Lister's name cannot fail to be mentioned. We have only to compare the surgery of the time before 1873 with the surgery as practised to-day to appreciate all that he has done for the science. Can it be for a moment questioned that Lord Lister has made operative proceedings possible which only twenty-five years ago would have been considered criminal? Undoubtedly, the most powerful agency in the development of surgery in this century has been the introduction of the antiseptic and asceptic methods of wound treatment which he initiated. It is due to his efforts that surgical wards have been freed from pyæmia, and the mortality of lying-in hospitals reduced to the limits of normal parturition. For the past twenty years honours many and great have been showered upon him. Oxford, Cambridge, Edinburgh, Glasgow, Dublin, Toronto, and now McGill, have vied with one another in hastening to do him homage. Our Sovereiga in conferring upon him the richly deserved distinctions which he bears with such gracious dignity only gives expression to the general feeling of bis countrymen throughout the Empire and his admirers the world over, We are glad, I say, to have him with us to-day: his presence is an intellectual stimulus and an energizing force in our deliberations.

It is, I understand, an unwritten law of the Association that the President shall not in his address encroach upon the topics which belong by right and usage to the readers of the main addresses and to the presidents of the various sections. I have observed that the majority of my predecessors have contented themselves with discoursing on objects and circumstances of local interest: they describe the town or city in which the meeting is held, or perhap they discuss questions of a public character. In the absence of an address on public medicine, others have taken that for their theme. It has been my unhappy lot to select and consider subjects only to find in quick succession that they had already been appropriated, either by the Association Journal, in describing so fully Montreal and its surroundings, or by the editors of the Official Guide or Souvenir, who have given a very comprehensive description of Canada, or by some of the gentlemen who preside over the sections, who, I have been led to understand, purpose discussing questions of medical educacion. I fear therefore, that what I have to say this afternoon will fall far short of the brilliant presidential addresses which members of this Association have been accustomed to in other years. Indeed when I look at the long roll of emin ent men who have been my predecessors in this high office--men oftentimes distinguished for their literary gifts as well as for their exalted position in the medical worldI confess that I marvel at my temerity in accepting so great a responsibility. In speaking of my predecessors allow me especially to refer to the retiring President, Dr. Henry Barnes, whose courteous and kindly manners, torether with his sterling ability, makes us all glad to know that his election as a Vice-President for life insures his continued official and active connection with the Association. Here might I also be permitted to say how greatly I appreciated the many kindnesses and courtesies extended to me by the President (Dr. Saundby) and members of the Council when in London last winter, making the initial arrangements for this meeting.

With respect to the other addresses, which it is custonary to deliver on these occasions, medicine will be dealt with by one whose reputation is now world-wide-by our Osler-whose professional education was in great part received in this city, and who, I am happy to say, is still a Canadian. How he has been able to escape the alien law is a puzzle to many; but he has really only been borrowed for a time; he is merely passing through the United States in bond. We are only waiting until we can find a place large enough to hold him, when we shall coax him back. Sorry am I that his old colleagues in his own department of medicine, Howard and Ross and Macdonnell, are not here to share with us the genuine pleasure we experience in finding him in the position which he occupies to-day. One of these, the late lamented Howard, had much to do with moulding his career and setting him to the task which he has so ably accomplished.

You will hear addresses in Surgery and Public Medicine, delivered by gentlemen who have devoted their lives to their special subjects.

Before proceeding further, however, allow me, for the benetit of those who may not be acquainted with the work of the British Medical Association, to give in as few words as possible a general idea of its organization.

The British Medical Association.

When, in 1832, Sir Charles Hastings, of Worcester, com. municated to a few of his personal friends the idea he had conceived of a medical association which should bring the whole provincial profession of England into a common brotherhood, it may be safely affirmed that he did not dream that he was laying the foundation of an association which would ultimately not only embrace the whole of the British Isles, but extend to that Greater Britain beyond the seas, and become an association of imperial magnitude and of imperial importance and significance. I have no hesitation in expressing my belief that the British Medical Association will be an important factor in bringing to a successful issue that great scheme of Imperial Federation which now exercises the minds, and, let me add, the hearts, of the leading statesmen of the Empire. Sir Charles Hastings' aim was to bring town into professional union with town, county with county ; now it has become the aim of the Society he called into being to add State to state-and may I not say continent to continent?-until all the nations and peoples who live under the British flag are brought within the beneficent influence of the Associa-

With respect to the objects of the Association, as set forth on its foundation, they may briefly be stated to be :

1st. The collection of speculative and practical information through essays, hospital reports, infirmaries, dispensaries, or private practice.

2nd. Increase of knowledge of the medical topography of England through statistical, meteorological, geological, and botanical inquiries; the investigation of the modifica tion of endemic and epidemic diseases in different situations and at various periods, so as to trace, as far as the recent state of the art would permit, their connection with peculiarities of soil and climate or with the localities, habits, and occupations of the people.

rd. The advancement of medico-legal science through snccinct reports of cases occurring in courts of judicature.

4 th. The maintenance of the honour and respectability of the profession generally in the provinces by promoting friendly intercourse and free communication of its members and by establishing among them the harmony and good feeling which ought ever to characterize a liberal profession.

During its earliest years the movements and proceedings of the Association were quiet and unostentatious, the meetings simple in their arrangements; but it was not long before medical societies began to join the newer body, and towns in all parts of the Kingdom soon came to regard it as an honour to entertain the Association. Gradually the best men of each distriet enrolled their names, and the membership increased so greatly that subdivisions into branches became a necessity. Each branch, with its own ordinary and annual meetings, was practically a replica of the parent society, possessing its 
own president, vice-president, secretary, treasurer, coun cil, and by-laws, subject to the approval of the Council of the Association, to which, besides, each branch sent representatives according to its numerical strength. In 1837, five years after the foundation of the Association, there were three of these branches formed, namely, the East Anglian, the Bath and Bristol, and the Lancashire and Cheshire. By the end of 1878 the A-sociation had spread over the whole United Kingdom, the total number of branches at that date being $30-$ one of the 30 , it is interesting to note, being Jamaica, the first Colonial branch to be formed. It was organized in 1878. Two years later we find that Australia appears for the first time, contributing three branches to the Association. Since then 36 more branches have been added, naking a grand total of 65 , with a collective membership of nearly 17.000. Of the branches 27 are Indian and Colonial. Doubtless before long those portions of Africa which are now becoming rapidly civilized will also add their quota, so that it is possible that within the lifetime of all present the British Medical Association will be represented wherever the British flag flies. As Nova Scotia is always to the fore in matters intellectual, it is not surprising that the first Canadian branch of the Association should have been formed in Halifax. It was started in 1887, four years ahead of Montreal, Toronto, Manitoba, and British Columbia. Canada has now seven branches, the Ottawa and Quebec branches having been formed within the last year. The formation of the Manitoba, Toronto, and Montreal branches was the immediate result of the visit to this country of Mr. Ernest Hart. In 1891, Mr. Hart, who has been editor of the British Medical Journal since 1867, and who has been well and truly described as the pivot on which the machinery of the whole Association revolves, passed through Canada in that year and addressed en route the members of the profession in Winnipeg, Toronto, and Montreal. Of the Manitoba branch, which began with 25 members, Dr. Ferguson was nominated as president, and Drs. Thornton and Lamont as vicempresidents. In Toronto the branch also began with 25 members, Dr. Macallum being nominated president, and Dr. 'Thistle honorary secretary. In Montreal the meeting was largely representative in spite of the short notice given, and 26 members of the profession at once signed applications for membership. The officers nominated were: President, Dr. (now Sir William) Hingston; first vice-president, the late Dr. George Ross; second vice-president, Dr. Jas. Perrigo. The members of the Council were : Drs. Roddick, F. W. Campbell, and Geo. Wilkins. In the course of a very happy speech made on this occasion by Mr. Hart he remarked that he looked forward to the time when the Canadian membership would be large enough to invite the Association to hold a meeting in Canada; and he hoped that the first meeting held outside the limits of the British Isles might be held in this country. Little did we think at the time that Mr. Hart's hopes would be so quickly realized. But the idea has ever been present with us and those who subseguently attended meetings of the British Medical Association in England have lost no opportunity of advocating the claims of Canada, and especially of this the metropolitan city of Canada, as a place of neeting for the Association.

One of the secrets of success of the British Medical Association is that it makes no distinction in the treatment of its members. Colonial members have all the privileges of the British members, and are always warmly welcomed at the headquarters in the Strand, and at the annual meetings. The Association has a large reserve fund of $\$ 40,000$ sterling, which is the joint property of the members, to be used for public or professional purposes, and any suitable applications for grants for medical research, whether from British or Colonial members, always receive attention.

A gentleman to whom the Association is greatly indebted is Mr. Franci; Fowke, who was appointed Secretary and General Manager in 1872. At that time the Association was in rather a precarious condition financially, owing to its deficient organization ; but shortly after Mr. Fowke took up the reins of office matters were found to improve. About the time he was appointed the subscriptions amounted to $\& 4,677$. Ten years later they had nearly doubled, the amount being $£ 9,147$; and in 1891 they had reached the very respectable sum of $£ 14,759$. It is interesting to note how closely the advertisements in the Jonernal kept pace with the increase in membership. In 1871 the amount received for advertisements was $\mathcal{E} 1,992$; in 1881 , $£ 6,089$, and in $1891, £ 14,568$. The head office, which had been in Birmingham, was moved to London in 1872, where, after two removals, the present commodious premises in the Strand were taken. In 1879 the Association began the printing as well as the publishing of its Journal. The library, which now contains 10,000 volumes, and which in cludes nearly every modern medical work of note, and many valuable books of reference, has developed in that time. That the British Medical Association is the largest and most influential guild in the world cannot be ques. tioned. Moreover the good it accomplishes increases from year to year, and more than keeps pace with the expansion of the Association. Imagine the mighty power of the col. lective action of 17,000 earnest men pitted against false dogmas and ever battling for the truth! It is not, how. ever, by greatness of numbers that the Association will be judged-it is by the diversity and quality of results. It is impossible to imagine any combination of circunstances which would render this great Association any less neces. sary or useful than it is to-day. It will undoubtedly con. tinue to grow in numbers, to increase in importance, and to be ever more and more an influence making for the amelioration and elevation of mankind.

The Canadian people, and especially the citizens of Mon. treal, are highly flattered and gratified that Canada should be the first country without the United Kingdom to be honoured by a meeting of the British Medical Association; and while they hope that it will not be long before the honour is repeated, our people are not insensible to the claims of other portions of the Empire, more especially the great island continent of the antipodes, Australia. Either Sydney or Melbourne would be a fit meeting place for such an imperial organization as this, and should the next meet ing which is held outside the British Isles be held under the Southern Cross our hospitable Australian kinsmen may count on a large contingent from the Dominion of Canada.

\section{Climatic Conditions.}

As it may be presumed that to the majority of those present here to-day Canada is almost an unknowu country I have thought that among one or two other subjects a few remarks on the atmospheric conditions and health resorts of the Dominion would not be without interest.

The best way to understand the atmospheric conditions of a country is first to understand its physical features. The physical features of Canada are very remarkable Broadly speaking the country is separable by climatic and physical conditions into three gruat regions, the Eastern Central and Western Regions, which approximately run north and south in the general trend of the continent. The Eastern Region, which includes the older provinces of the Dominion, Ontario, Quebec, Nova Scotia, New Brnnswick, and Prince Edward Island, besides the great for territory stretching far to the east and northeast of James Bay, extends from the Atlantic to Lake Superior and the chain of Great Lakes running in a northerly direction from Lake Superior to the Arctic Ocean. Between this greal chain of lakes and the eastern base of the Rocky Mountain is the immense interior continental plain which constitutes the Central Region of Canada, its southern part consisting of open prairie, its northern part of forest lands. The third part of the division, the Western Region, is natriall very well defined, consisting of the wide and wild mountainous border of the Continent on the Pacific side-the Rocky, Selkirk, and Gold Ranges, which form the great Cordilleran belt, whose average width in Canada is 400 miles.

Eastern Canada, our first and largest region, is geolog ically of very ancient origin. Here geologists have placed the nucleus of the continent- the broad belt of crystalline rock of great antiquity called the Laurentian Platean. This region is remarkable for its immense number of lakes, large and small, and for its irregular and winding rivers with numerous rapids and falls. Between the Laurentian Plateau on the north and the Appalachian mountain sys. tem on the south, lies the great Valley of the River St. Lawrence. The basin of this majestic river covers 530,000 square miles, of which 460,000 are in Canata. Above the city of Quebec, the base of the Laurentian highlands and the ridges of the Appalachian system diverge, and the mighty river flows through an extensive low country of notable fertility, in earlier days the great granary of Canada.

It. may be added en passant that Mount Royal, which gives such distinction and character to our city, represents the basal remnants of a volcanic vent of great antiquity. From its picturesque summit may be seen similar abrupt elevations far off towards the east and south-Montarivlle, Beloeil or St. Hilaire, Mt. Rougemont, with Mt. Yamaska behind it, Mt. Shefford, and the conical Mt. Johnson or Monnoir. The Adirondacks are visible in the distance to the south-west, and the Green Mountains to the south. east.

Included in the Eastern Region is one of the most remarkable geographical features of Canada-the great 
fresh-water lakes or inland seas, Superior, Fin ron, Erie and Ontario, which form the perenial reservoirs of the St. Lawrence. Together with Michigan, which is wholl. $y$ in the United States, they have an aggregat, area of 94,750 square miles, an area larger than that of I $x$ reat Britain. They stand at four dirtinct levels above the seaOntario 247 feet, Erie 573, Huron 581, and Superior 602. The Niagara Falls, the greatest and most impressive of the natural wonders of our continent, are the dir ect result of the great height of Lake Erie above Lake Or tario, tho river connecting the lakes being only a few miles long. Besides the St. Lawrence, Eastern Canada he s several other great rivers, notably the Ottawa, which ha; a course of 1,800 miles and a basin of nearly $1,000,000$ squi, re miles, the St. Maurice, the Saguenay, and the St. John, the glory of New Brunswick, which, together with the Atlantic Slope, has a basin of 50,214 square miles. The Central and Western Regions also have their abundant share of large and small lakes and great rivers, an account of which would fill reams of paper. It should be noted that the Canadian rivers and lakes collectively cover as area of 130,000 square miles, and contain one-half the frosh water on the globe.

I draw special attention to this series of vast lakes and rivers because it exerts an immense and bentficent influence on the climate of Canada. It preserves the mean temperature while the land experiences the extremes. In summer the water is cooler and in winter warmer than the land conditions, which tend to modify the differences and to favour uniformity of climate. Without these waters, too, we should have vast regions of comparatively little value, as in Africa, Asia, and in the United States west of the Mississippi River, where large trac js of land far from water are nothing more than arid wastes. Our climate is more uniform than that of Furspe; the meteorological differences are produced by posit:cn alone, but Europe has a higher mean temperature, and the extremes there are not so marked or so wide atart as in Canada. Owing to the great area of Canada, 1 xtending: over $20^{\circ}$ of latitude, or from the latitude of Constantinople to that of North Cape in Norway, the range of ter perature is naturally very wide. 'The southern boundary stretches; over fully 4,000 miles, along which line we find that Southern Ontario has the latitude of Centrel Italy, Nc.va Scotie that of Northern Italy, Manitoba and Vancouver that of Central Germany. Speaking generally, the Canadian summer may be stated at $60^{\circ} \mathrm{F}$. to $70^{\circ} \mathrm{F}$.

From its vast and varied extent, Canada may be said to be the possessor of several climates. Taking Solly's classification as to position, we have in Canada all ihe three land climates, the low, the medium, and the high. The first has an elevation up to 2.500 feet, the second up to 4,500 , and the third from 4,500 upwards. As to temperature and humidity, Canada comes under the category of "cold, moderate, and dry."

\section{HEALTH RESORTS.}

In the eastern region of the Dominion there are at least two localities which have been proved to possess many of the qualities which constitute a climate for convalescents from fevers and other depressing diseases, and also for consumption in the incipient stage. I refer to the region in the Province of Quebec among the Laurentians north of this city, of which the village of Ste. A oathe is jise centre; the other being the Muskoka District, in Ontario.

The first has been called the Adirondacks of Canada, having many of the features, physical and clims,tic, of that now celebrated plateau situated in the north-eastern part of New York State, and stretching from the Mohawk Valley in the south 150 miles north, almost to the frontier line. The average elevation of the two regions is about the same, being from 1,600 to 1,800 feet. The immense pine forests, together with the moderate temperature, constitute the chief characteristic of the Canadi an district, from the medical point of view. No very systematic meteorological observations have yet been taken of the St. Agathe region, but the indications will probably prove to be very similar to those of the American resort. It is in contemplation to erect a Sanitarium on Trembling Mountain, overlooking the village of Ste. Agathe, which will doubtless in time rival the Adirondack Cottage \$stunitarium near Saranac Lake Village, which has proved such a marked success under the able management of Dr. E. L. Trudeau. The elevation of the Sanitarium will be 2,500 feet, thus having an altitude of nearly 700 feet greater than the establishment at Saranac. It is the invention of the Quebec Government to set apart a sufficient portion of the Crown Lands to form a natural park in that part of the Province. It will be called the Trembling Mouritain Park, and will cover an area of 100,000 acres of land, in which are several beautiful lakes. Within the boundaries of this park the Sanitarium $\nabla$ ill be constructed. There is, therefore, no reason to doubt that we will shortly hare witilin our own lines a health resort possessing all the advantarses of the Adirondacks rugion, and capable of affecting tor good the same class of patients now so decidedly benefitted by a residence in those mountains.

One hundred miles rorth of Toronto, in the highlands of Ontario, is the Muskcka Lake region, an area of about 10,000 square miles, perhaps the most picturesque porrion of the whole Province. Within this district, which has a mean altitude above the sea of about 800 feet (200 feet above Lake Huron), thare are nearly a thousand lakes and ponds, connected by innumerable streams. The chief lakes are Muskoka, Rosseau, and Joseph. These contain about 400 islands. It is a regrion abounding in pine forests; the climate is dry, and the air pure and invigorating. The Muskoka region has heen found undoubtedly to possess remarkable advantages for those with phthisical tendencies. The death rate from phthisis in this section of Ontario is proved to be less than one-tenth the rate which obtains in other parts of the Province. At Gravenhurst the Muskoka Cottage Sjanitarium for the cure of incipient phthisis has recently been founded, under the best auspices, with accommodation for forty patients. The present Sanitarium consists of a large and well-planned main building, surrounded vithin easy distance by a number of small cottages. The grounds, which embrace seventy-five acres, are situated on Lake Muskoka. Pine forests and rocky ridges protect the buildings on the north and west sides, whence come the colder winds in winter. Like the Adirondacks Sanitarium, the intention is to occupy it all the year round. 'The progress of this institution, at present in the experimental stage, will be watched with much interest.

In the Central Region of Canada, that section of the Northwest Territories known as Southern Alberta-the home of the cowboy-has much to recommend it as a health resort. This strip of urairie and hill country is bounded on the north by the Canadian Pacifie Railway, and on the south by the International boundary line; its eastern boundary extends as far as Medicine Hat; its western boundary to the sumnit line of the Rockies and British Columbia, comprising in all an area of about 20,000 square miles. The plain here has an elevation above sea-level of 2,700 feet, which gradually increases up to the entrance of the Crow's Nest Pass, where the elevation is 4,500 feet Calgary, the capital o: Alberta, is itself 3,500 feet above sea-1evel. With this gradual incline from a low to a high level altitude, the patient can choose the locality which suits his particular case. In a long experience Kennedy knew of only two cases of phthisis originating in that country-one of acute tuberculosis with a hereditary taint, which proved fatal; the other, of the ordinary type, re covered without leaving the place. He claims for the climate of Southern Alberta a dry asceptic atmosphere and a dry soil, the greatest possible number of sunshing days (90 por cent.), with cool nights. Patients can live there all the year round, and with the exception of an occasional snowstorm, which may cover the prairie to a varying depth, nothing need interfere with their practically living in the saddle. The so-called Chinook wind has a remarkable influence over all this western section of Canada. It is a warm wind which blows with varying intensity from west to southwest. NicCaul, who describes it very graphically, speaks of its approach being heralded by the massing of dark clouds above the mountain tops, and a distinct wailing and rumbling from the passes and gorges. Its effect in winter is little short of miraculous. When the real Chinook blows the temperature often rises in a few hours from $20^{\circ}$ below to $40^{\circ}$ above zero. The snow which in the morning may have been a foot deep, disappears, and before night 3 verything is dripping. But in the space of a single day all the water is lapped up by the thirsty wind, and the prairie is so dry that a horse's hoof hardly makes an impression.

The cases which have been most especially benefitted by Alberta's climate are pulmonary tuberculosis in the earliest stage, although neurasthenics and anæmic women are likewise favourably affected to a marked degree. It is well-known that delicate lads sent from the British Isles to this section of the Northwest to work on the cattle ranches become in a year or two healthy and vigorous men, and are scarcely recognized on their return.

Still farther west, and nearly midway between Calgary and the Pacific Coast, is the beautiful Valley of Kamloops, another all-the-year-round resort which has much to commend it to those suffering from many forms of tubercular disease. This picturesque valley, which lies between the Rocky Mountains and the Cascade Range, has a low alti- 
tude climate of 1,100 feet, but is exceedingly dry, showing an annual rainfall of only 11.05 inches, with an average of about 75 rainy days in the year. The rain soon disappears, the soil being light and gravelly. In this region we have an illustration of the local variability of climate recently pointed out by Bryce, who, in referring to the two not very distant localities of Vancouver and Kamloops, showed that whereas the former has an annual rainfall of $3 \tilde{0}$ inches, the latter records but 11 inches and a decimal. The mean annual temperature of the Valley of Kamloops is $46.03^{\circ} \mathrm{F}$., the annual range being only 22.8 . The tuberculous patients who appear to be most benefitted by a residence in Kamloaps are those in whom there is a tendency to chronic congestion. Cases of bronchitis are likewise said to do well there. The climate can also be recommended for consumptives where cardiac disease exists as a complication.

That Canada is an exceptionally healthful country is the general testimony of the army and navy surgeons who have been stationed in Canads with the different regiments from the time of the conquest to the present day. Crawford, who was attached to one of the regiments stationed in Montreal many years ago, and who subsequently left the army and practised in this city, published elaborate and carefully collected statistics to prove that few portions of the British Empire have a climate equal to that of Canada. In fact his statistics prove conclusively that out of every 1,000 of the troops stationed at the various garrisons throughout the Empire, the percentage constantly ineffective from sickness was smaller in this country by 7 per cent. than at Gibraltar, which was then taken as the type. I think it can be satisfactorily proved that Canada is expressly fitted to develop a hardy race capable of great endurance. The races of the British Isles and the French race have certainly not degenerated here. Hingston proved this very conclusively some years ago by observations made upon the medical students attending the various schools in this city. He found that the lumbar strength of the British Canadian of the third generation exceeded by 20 lbs. that of the recently arrived English and Scotch students. But the French-Canadian of the tenth generation did better than all by nearly $30 \mathrm{lbs}$. Not only has the French-Canadian increased in strength but also in height and weight over the original Normandy stock.

Has the intellectual improvement in our people kept pace with the physical? We are a modest people, but I think we can say it has. We have a very respectable lit erature of our own, but the best intellect of the country is as yet absorbed in the practical alfairs of life, and has too seldom found expression in art and literature. It is not very long since a distinguished American litterateur Charles Dudley Warner, gravely attributed what he called the literary inactivity of Canada to the coldness of the climate. He said, in short, that the cold benumbed our intellectual faculties, and we had to spend so much of our energy in trying to keep warm that none was left for any other purpose. It must be adnitted that if we measure the intellectual capacity of our people by the number of books produced in Canada the result is not all we might desire; but the climate is not to blame. Especially it is not the cold, for the winter is the season devoted pre eminently to intellectual effort and intellectual amuse ments. If Mr. Warner had said that the heat of our summer was an unfavourable factor in our intellectual life he would not have shot quite so wide of the mark; he would not have been right but he would not have been quite so wrong. The very vicissitudes of our climate, by training the system to endure severe physical conditions, must react favourably upon the mental attitude.

\section{Canadian Spas.}

We have in Canada several mineral springs of undoubted therapeutic value, and they are pretty generally distributed all over the Dominion, although differing materially in temperature and composition. 'T'he best known 'Canadian spas are the Caledonia, the St. Leon and the Plantagenet Springs, in the Province of Quebec, and the Banff Springs in Alberta. Other springs in the Province of Quebec are the Abenakis and the Caxton. Besides these there are at least three or four artesian wells or springs. Of these the chief are the Laurentian Spring in the east end of this city (a mild alkaline water with sodium bicarbonate as its predominating ingredient), and the Radnor, a well of some considerable repute situated in the County of Champlain. This was discovered a very few years ago when boring for water to supply the workpeople engaged at the well known Radnor Forges. It has been likened to the German Seltzer, many of the properties being alike. It bius fair to become a rival in time of the celebrated Apollinaris water to which it is preferred by many. The well is over 400 feet in depth. In the Province of Ontario the chief springs are the Winchester and the Preston, and those in the town of St. Catharines, near Niagara Falls. The best known and the most popular are the Caledonia Springs, situated on the line of the Canadian Pacific Railway about midway between Montreal and Ottawa, and about nine miles from the Ottawa River. They consist of four springs-the gas, the saline, the white sulphur, and the intermitting or Duncan spring. The tirst three are situated within a distance of three or four rods of each other, and the mouths of the latter two are not more than four feet apart. The intermitting spring is situated about two miles from the others. This is so named because the discharge of gas is not regular, some minutes elapsing between the periods of quiescence and disturbance. The average temperature of these springs is about $46^{\circ} \mathrm{F}$. The intermitting spring has the largest percentage of chloride of sodium, and differs from all the others in possessing a greater portion of chlorides of calcium and magnesium. It has also nearly twice the proportion of carbonate of magnesium that the others contain. It has been found that taken judiciously and under advice these waters have a remarkable effect in subacute and chronic rheumatic conditions. People sutfering thus are found flocking to Caledonia from all parts of this continent and even South America, especially during the months of July and August. Gouty conditions depending upon liver disturbances also yield very readily to these waters. The waters of St. Leon and Plantagenet are similar in many respects to those just described, and as a rule suit the same class of patients.

All the springs so far mentioned yield cold waters. But Canada also possesses the most famous thermal springs on this continent.

Banff, now a picturesque town magnificently situated in the heart of the Rocky Mountains, yet within the limits of that division of the Norchwest Territories known as Alberta, has become one of the noted health resorts, although frequented more on account of its remarkable thermal springs than for its climatic advantages. The town is built on the banks of the Bow and Spray rivers, two largeglacier streams, and is surrounded by mountains towering many thousands of feet above the level of the sea. The winter is short, beginning in December and ending in February, and is much milder than Ontario. Very little rain falls, and the days as a rule are bright and cloudless. Prolonged periods of warm weather are experienced during winter. March and April are variable; May is warm and bright; June is the month in which the greatest rainfall occurs; July August, September, and October are very warm and very dry, with cool nights. At all seasons with the exception perhaps of June the air is dry and notably aseptic. It is positively stated that no case of malaria or tuberculosis has ever been known to originate at Banff. Independently of the springs, then, Banff has much to recommend it from a climatological stand point.

The far-famed Thermal Springs of Banff were only discovered some 15 years ago during the construction of the Canadian Pacific Railway. At its source in the mountain side it has a temperature of $1277^{\circ} \mathrm{F}$. and the air is charged for some distance around with the steam emitted from the pool to which the water flows. The most recent analysis shows it to contain the following ingredients:-

Calcium sulphate.

Magnesium sulphate..................... 12.39

Calcium carbonate.

Sodium sulphate.

Sodium carbonate.

Silica. .

Organic mattèr

traces.

The waters of Banff have been used with great benefit in rheumatism, gout, sciatica, and glandular affections, in certain forms of skin disease, and especially, it is thought, in tubercular affections of the skin and mucous membrane. Aided by the admirable climatic conditions the waters have also been found to benefit in a marked manner functional diseases of the liver, stomach and kidneys, and tubercular joint affections. In debilitated constitutions from any cause the activity of the skin is noticed to be in creased, the heart and vascular system strengthened and the muscular and nervous systems much improved in tone. Rachitic and delicate children are much benefited by the Thermal Springs. This seems a large order; but the therapeutic effects of these springs have been carefully studied by competent medical men who have been stationed ther for some years. 'The climate doubtless assists materially the action of the waters in very many cases.

I doubt if the Canadian profession sets a sufficiently high value on the therapeutic properties of our own min- 
eral springs. When visiting the Spas of Great Britain and Europe, one is impressed by the caution exercised by patients in the method of using tne waters which have been prescribed. There, competent local medical men are always to be found who can give the proper advice regarding the water to be taken for the ailment from which the patient suffers, and the judicious use of baths. Here, unfortunately, in many places no professional advice is available, and the patient consequently does very much as he pleases, or as the hotel proprietor may advise, and in consequence more harm than good constantly follows the use of the waters.

\section{Medical Education in Canada.}

The general question of medical education is one of great importance and of unceasing interest, nor is this interest confined to the profession : it is becoming universal. The needs of medical education are fortunately being more fully realized by those who on account of their wealth and influence are in a position to render that substantial assistance which is so requisite. The time was when everv medical school was a purely proprietory concern "run" for the money that was in it. "We feel in Canada, and I think I can speak for the profession in the neighboring Republic, that this day is passed, that highminded philanthropists like the Right Hon. Lord Strathcona and Mount Royal, the late John Henry Molson, the MeDonalds, the Drakes, and others with us, and the Johns Hopkins, the Stanfords, the Vanderbilts, the Rockafellers, the Miss Garretts, and others with them are beginning to realize that unendowed instruction in medicine must lead to imperfect resuits, and that private endowment, in the absence of state aid, has become an absolute necessicy to a proper medical training. I am not an advocate for state aid to universities, and I rejoice that the university to which I have the honor to belong $\mathrm{ls}$ not so dependent, as it might thus be deprived of those gifts of private munificence to which I have just referred. All honor to those far-seeing, open-handed men and women who are giving of their abundance in order to elevate the standard of
medical education and by so doing beneflt their kind. As Gould very tersely puts it in one of his clever articles: "I think our reliance must be upon private bequests, and these can be secured only as we interest the rich. We must never weary in showing the neglect of the greatest, most palpable, most certain means of doing good. There is a strange fatality in men, an unaccountable inability of seeing the need that lies nearest the good that is dearest. There is more money to-day devoted to astronomy than to the prerention of disease. It is positively wonderful to think that men should be more interested in stars and constellations than in their bodies and their physiological life."

A question which is now-a-days agitating the minds of those especially interested in medical education is the kind of ground work which is likely to bear the most direct relation to the future studies of the medical student. I think it is now conceded by all that he is placed at a greater advantage who first passes through an arts or a science course. I am happy to be able to report that from 15 to 20 per cent. of those who are studying medicine in this country to-day have had a collegiate training in either arts or science. Which of the two should the parent or guardian choose? Had I a son whose instincts were in the direction of medicine, I think I should choose for him the science course. The late Professor Huxley thought it was a most self-evident proposition that the educational training for persons who proposed to enter the medical profession should be largely scientific; not merely or even principally because an acquaintance with the elements of physical and biological science is absoluteiy essential to the comprehension of human physiology and pathology ; but still more because of the value of the discipline afforded by practical work in these departments in the process of observation and experiment, in inductive reasoning and in manipulation.

The subjects in the science curriculum might be specially selected for the future medical student. Of course it may be said in favour of the arts course that many of the subjects such as physics and chemistry constitute part of the curriculum; but then calculate the loss to the future surgeon of that training of the hand and eye which would lead him up to be a skilled operator; or to the scientific physician whose complicatcd instruments of precision em ployed in the diagnosis of disease need some mechanical knowledge for both their use and repair. Besides the number of those has been increasing in number and com plexity with the increase of scientific knowledge.

But can we not make a new departure: can we not urge that a special scientific education be arranged by the universities for those who desire to enter the medical profession? Such a course would embrace elementary Latin and Greek, French and German, physics, chemistry, biology, psychology, elementary mechanics, a practical laboratory course on electricity and drawing. After two years' study this might entitle the successful candidate to the degree of Licentiate in Science.

Something of this kind has been recently attempted in the University of MeGill. By a special arrangement with the Faculty of Arts it is now possible for students to obtain the degree of B.A. along with M.D., C.M., after only six years of study. It has been decided to allow the primary subjects (anatomy, physiology, and chemistry) in medicine to count as subjects of the third and fourth years in Arts. It follows, then, that at the end of four years' study a student may obtain his B.A. degree and have two years of his medical course completed. The last two years of study are of course devoted to the third and fourth year subjects in medicine. A certificate of Licentiate in Arts will be given along with the professional degree in medicine to those who previous to entrance upon their professional studies proper have completed two years in the Faculty of Arts, and have fully passed the prescribed examinations therein. By this plan also during the first two years of the arts course the medical student practically completes his studies in physics, chemistry, botany, and elementary psychology. This scheme is still in the experimental stage, but there is every reason to believe that it will result satisfactorily. What deters so many from taking a full course in Arts or Science before entering Medicine is the length of time consumed before the doctorate degree is reached, although I hope the time is not far distant when every graduate in Medicine in Canada shall of necessity be also a graduate in Arts or Science. I might state that the standard for the ordinary matriculation examination for entrance to medicine exacted by all universities and licensing boards in this country is, with one or two exceptions, very high. I doubt if the requirements in this way of the Medical Council of Great Britain are any higher.

Now as to the purely PROFESSIONAL portion of medicine, I might state that we have in the Dominion of Canada no fewer than 11 medical schools, including one for women only, all having the power of granting degrees, and all connected directly or by affiliation with university bodies. To enumerate them: Beginning with the Atlantic Provinces, we have in Halifax the medical school attached to Dalhousie University, the only medical school in the Maritime Provinces; in this province there are four schools, Laval in Quebec, Laval in Montreal, McGill and Bishop's in Montreal ; in Ontario, four schools, namely, the Royal College of Physicians and Surgeons, Kingston; the University of Toronto Medical Faculty, Trinity Medical College, and the Ontario Women's Medical College, in Toronto ; in London, Ontario, the Western University Medical Faculty; and lastly, in Winnipeg, the Manitoba University Faculty of Medicine. All told, we had in Canada, during the last winter sessions, 286 teachers, including professors, lecturers, and demonstrators, and 1736 students. The tendency for the past two years has been to increase the teaching staff quite out of proportion to the increased number of students. Taking McGill we find that there are in the present year 53 teachers for 388 students, being a proportion of nearly one to eight. Laval, in Montreal, has 36 teachers and 197 students, a still greater proportion. The Toronto School of Medicine had during the past year 41 teachers and 293 studenrs. We find that this propor. tion compares well with the larger schools in the United States; thus, in 1893, there were in Harvard Medical School 71 teachers to look after 471 students; at the Columbia Medical College in New York with 661 students there were 105 teachers ( 1 to 6 ); in the University of Pennsylvania the teaching staff in the same year comprised only 84 members with 825 students, being a littie over 1 to 10 . What does this mean? Ten years ago when MeGill had 237 students, a staff of 23 professors and demonstrators was considered sufficient. Why are so many more thought necessary now-a-days? The number of subjects taught has not increased very much. The answer is that the subjects are differently taught, the oldrashioned daily didactic lectures are now given two or three times a week only; although I should be sorry to see them further reduced in number, I believe that so many are absolutely necessary. It is in the dissecting room, the chemical, physiological, therapeutical, and pathological laboratories that we see the change. These which -before were for the most part only "side shows" are now made to hum with the practical work. which is done within them, while demonstrators are moving about busily, en. gaged in examining and instructing. 
In clinical teaching also we have made marked advances. A creation of the last few years is the clinical demonstrator, who takes small classes of students into the wards or the out-door depart nent of our hospitals and glves them that "bedside instruction" which is so essential, leaving the clinical professor to deal with the full classes in the lecture or operating room. Thus each student is enabled personally to examine the case, to study the physiognomy of disease, and to make deliberate, thorough and systematic examination. He thus learns to use his special senses and gets into careful habits of observation which once thoroughly acquired will be found to contribute largely to future success. With this in view we encourage students to attend the out-pationt department of the hospital as early as the second year.

In order to make the clinical instruction more complete and more thorough, chemical and bacteriological laboratories have been added to the pathological departmerts of our hospitals. Thus it will be seen that laboratory methods everywhere prevail, all with the idea of developing the scientific spirit in students and of cultivating methods of thought with observation.

The question sometimes arises, however, may the student not be getting too much co a good thing? Is it not possible that laboratory teaching may be overdone? because, as Welsh very truly says, "The student whose knowledge of a subject is derived exclusively from labor atory courses is likely to lose his perspective in details, to acquire only a fragmentary knowledge of the subject, to fail to comprehend the general bearing of observed facts, and not to acquire the general principles and systematic conceptions which are essential. Laboratory work should be accompanied and supplemented by the reading of text-books and by lectures." I am convinced that with us in Canada laboratory work is not overdone, but on the contrary, in some departments needs and deserves further encouragement. I hope every laboratory teacher in the country realizes that the object of a college is to give a good general education, and not to make experts in various branches. I have long felt myself, however, that the didactic lectures were being unfairly dealt with. There is a feeling abrcad that they should be practically elbowed out of sight. I think the didactic lecture has its place in the medical course; and while quite feel that the old plan of compalling students to listen to five didactic lectures a week in all of the great subjects was a mistake, I still feel that a good lecturer can teach in this way a certain something which cannot be imparted by practical instruction or by recitations. The personal influence of a good lecturer very often makes an impression which nothing else can make; and if such lectures are made also demonstrative, as by the use of diagrams, the lantern, experiments, \&c., they must of necessity fill a very important place in the medical course.

Hygiene is at last receiving in this country the attention which its importance demands; all medical schools in Canada have facilities for teaching it. In McGill University the scope of the teaching of hygiene has been vastly extended, thanks to the generous indowment of that de partment recently by the Chancellor, the Right Hon. Lord
Siratherna and Mount Royal. The subject can now bo taught in a scientific and, at the same time, eminintly p aclical manner. There will be trree teachers associated with the professor himself, viz., the heads of the Depart ments of Practical Chemistry, of Pathology, and of Bacteriology. This is following very much the German system, also adopted by the University of Pennsylvania, the chemical and bacteriological aspects of the subject being really regarded as the most important. An extensive working museum, with sanitary apparatus of every kind, forms part of the scheme, and will doubtless add greatly to the efficiency of the course when it is completed. Should the experiment succeed, you will be rejoiced to hear at no distant date that the other schools in Canada have followed the lead of their elder sister.

I fear I have given you a very imperfect idea of medical education in Canada; and it may be charged against me that I have been partial in my description to my own University; but I assure you that such was furthest from my thoughts. The Medical Faculty of McGill University has the right of semiority and might fairly, I think, be taken as a type of Canadian Medical Schools. Be assured thire is no mean spirit of rivalry abroad. We are all Wuking with one object only, the advancement of medi cive in Canada. The teaching facilities of some medical schools in this country may be and are actually greater thath others, owing to the munificerce of citizens, and the school attached to McGill is, I am happy to say, in that position; but although assistance has been rendered in a general way, with two exceptions, the chairs are still un- endowed. Yet we liave great expectations which we hope will be realized in the near future. Let us hope that our sister unsversities throughout Cansda will be equally for. tunate; so that before long we shall be able to report that we are al' marching abreast equally equipped.

The facilities for clinical teaching in the larger cities of Canada ace admirable. Speaking for the city of Montreal, we have in the five general hospitals, the Hotel Dieu,
Montreal General, Notre Dame, Roval Victoria and West. ern Hosp tals, nearly 800 beds. The number of students attending: the three medical schools was last session 646; and cons dering that only about half-those of the third and fourth years-have access to the wards, there will be at least wo beds for each student. The number of outdoor patients attending the five hospitals daily would aggregate at least 300 , so that there could be no possible cause for complaint regarding both the quantity and quality of clinical material available in this city.

While on the subject of hospitals, I would take this opportun ty of saying that the training schools attached to the larger English hospitals are in a very flourishing condition and are found to contribute not a little towards the thorcughness of the practical teaching. It was my intention to have referred at some length to the whole question of Nurses and Nursing, but the limits of this address f.orbid. I might say, bowever, while as a pro. fession ve feel the absolute necessity for the training school, and thoroughly appreciate the services of the well trained rurse, both in hospital and in private practice, there is the fear that the supply may exceed the demand. A project, is on foot now, however, which may delay, if not actually prevent, such a result. I refer to the recent establishment by that most estimable and charitable woman, the Countess of Aberdeen, of the Victorian Order of Nurses-another outcome of the jubilee of our beloved Queen. Her Excellency's idea in establishing this order is to supply the sparsely settled parts of our great Northwest, the outlying districts of Canada generally, and the poor in towns and cities with nursing aid. In this great work hurdreds of nurses will in time be employed. The scheme, which is purely non-sectarian, and appeals to all, irrespective of nationality, when thoroughly worked out and more generally understood will become one of our national nstitutions. Let us wish it every success.

\section{Medical Legislation in Canada.}

Time vill not permit of my discussing the subject of medical l zoislation in Canada at any length; and besides you will ind it very fully treated in the excellent Official Guide and Souvenir, prepared for you by the Executive Committee. In addition I might explain, however, that when the British American provinces became confederated in 1867, under the British North America Act, the governance of uducational matters was taken.away from the Federal "uthorities and handed over to the provinces, each to lcok after them in its own way. In consequence we have sirce had a curious complexity of Medical Legislation, there being practically no uniformity among the provinces in regard to standard of study or qualification for practiee. Each province has its own medical board or medical council, as the case may be, which has the power to grant a licence to practise either after examination or on simply presenting the diploma of certain recognized universities. In the provinces of Ontario and British Columbia an examination is exacted; in the others the licence is given under certain restrictions on presentation of the degree, although in the Maritime Provinces an examining board is now about to be established. In this way, as can readily be seen, a Chinese wall is built round each province, and the frontier is carefully guarded so that it is unsafe for a medical man to pass from one to the other unarmed with a licence, because of the risk of fine or even imprisonment. Such a condition of affairs is hardly credible and probably exists nowhere else to the same extent. What is the remedy? Two remedies have been suggested-either the establishment of a central ex amining board in each province, with a uniform stan clard of matriculation and a uniformly high standard of curriculum which shall in time lead up to a genera scheme of reciprocity; or secondly, a Dominion Examining Board. The first scheme is at present under serious con sideration, although there are many difficulties in the way of its accomplishment, none of which is insuperable however, providing a spirit of conciliation prevails. The second all truative (a. Dominion Examining Board) would in many respects be nore desirable, because not only could the licent ate practise in any part of the Dominion, but he could register in Great Britian, and thus receive recognition all over the Empire. As you are doubtless aware, we as a profession suffer in this country from being inhabi. 
tants of provinces which are confederaied. In an enactment, now of some twelve years' standing, the British Medical Council decided, in effect, to recognize the degrees of universities situated in autonomous provinces only. As a consequence, Australians obtain privileges which are denied to us, being permitted to register in Great Britain without examination. We are being punished for belonging to a colony whose form of Government is longing to a colony whose form of Government is
recognized to be in advance of theirs and likely to be imitated by them: Let us give our Australian brethren a hint: if the confederation of your provinces be in contemplation, see to it that all matters of professional education are left in the hands of the Central Government, at least as far as qualification for registration is concerned. By so doing you will avoid the almost inextricable tangle in which we in Canada find ourselves. Let common school education go to the various provinces if you will, but for the profession of medicine (and doubtless law also) there should be a uniform standard of matriculation, a nniform curriculurn of medical studies, and one Central Examiniug and Registering Board composed of the best men from all the universities. We hope in Canada to reach that ideal at no distant date; in fact $I$ have the very best authority for stating that it is not im possible of accomplishment. Some scheme of reciprocity first arranged would doubtless make the task less difficult, but failing that, our duty is to arrange for somelegislation which shall give our better and more ambitious students an opportunity of passing a Dominion Licensing Board (or whatever it may be called) which shall give the privilege of praccising their profession not only in any part of their native country, but in any part of the world over which the British fiag flies. Such a scheme need not interfere in any way with the autonomy of the provinces. Each may still retain its Provincial Board for the purpose of examining and issuing licences to those candidates who are satisfied to practise their profession in the limited sphere of their own provinces. I think the legislators of this country will some day (and not far distant either) be induced to see that the system which at present obtains is unworthy of a great and growing country.

In conclusion, allow me to express the hope that the arrangements made by the Executive Committee for the entertainment of our guests may meet with appreciation and approval, and that the memories of the brief sojourn here may be all that is bright and happy. The loyalty and unanimity with which the profession throughout the Dominion has cooperated with us in Montreal to make this meeting of the British Medical Association a success from every point of view, deserves and receives our hearti est thanks. We are also greatly indebted for the kind and ready assistance of the Dominion Government, the Quebec Government, and the Civic Government of Montreal. Our hands have been strengthened and the cause we have so much at héart has been furthered by the active good-will of the country's official representatives.

One word more: It is a good thing to be here to-day, in the midst of this great gathering so full of power and vigour. The fruits of such a gathering should be tangible, enduring, not ephemeral, not for to-day, but for all time. To our kinsmen from beyond the great seas, let me express the earnest hope that in the future our kinship will be a more real and living thing than in the past. We are members of one great family, members one of another, in a peculiar and very real sense. Let that once be recognized, and the statesman's task will be an easy one. In more than words has Canada shown herself worthy of her high heritage, worthy of a part in the Empire, worthy to share in its trials and its triumphs. We, who know her history, caul say with well-founded confidence:

So in the long hereafter this Canada shall be

The worthy heir of British power and British liberty

Spreading the blessings of her sway to her remotest bounds, While with the fame of her fair name a continent resounds, True to her high traditions, to Britain's ancient glory,

of patient saint and martyr, alive in deathless story;

Strong in their liberty and truth to shed from shore to shore

A light among the nations till nations are no more.

The drive round the city, in the electric cars, at the conclusion of the President's opening address on Tuesciay, afforded the visitors an excellent means of seeing the more populous parts of the town, and was; an exceilent idea on the part of the executive. Some eight or nine cars were well filled with members of the protession and the ladies and friends accompanying them.

\section{Adaress in Inledicine}

$\mathrm{BY}$

WILLIAM OSLER, M.D., E.R.C.P.,

Professor of Medicine, Johns Hopkins University, Baltimore.

\section{BRITISH MEDICINE IN GREATER BRITAIN.}

To trace successfully the evolution of any one of the learned professions would require the hand of a master, of one who, like Darwin, could combine the capacity for patient observation with philosophic vision. In the case of Medicine the difficulties are enormously increased by the extraordinary development which belongs to the his. tory of the present century. The rate of progress has been too rapid for us to appreciate, and we stand bewildered and, as it were, in a state of intellectual giddiness, when we attempt to obtain a broad comprehensive view of the subject. In a safer 'middle flight,' it is my purpose to dwell on certain of the factors which have moulded the profession in English-speaking lands beyond the narrow seas, - of British medicine in Greater Britain. Even tor this lesser task (though my affiliations are wide and my sympathies deep), I recognize the limitations of my fitness, and am not unaware that in $m y$ ignorance $I$ shall overlook much which might have rendered less sketchy a sketch necessarily imperfect.

Evolution advances by such slow and imperceptible degrees that to those who are part of it the finger of time scarcely seems to move. Even the great epochs are seldom apparent to the participators. During the last century neither the colonists nor the mother country appreciated the thrilling interest of the long fought duel for the possession of this continent. The acts and scenes of the drama, to them detached, isolated and independent, now glide like dissolving views into each other, and in the vitascope of history we can see the true sequence of events. That we can meet here to-day, Britons on British soil in a French province, is one of the far off results of that struggle. This was but a prelude to the other great event of the eighteenth century, the revolt of the colonies and the founding of a second great English-speaking nation, in the words of Bishop Berkeley's prophecy--

"Time's noblest offspring."

Surely a unique spectacle that a century later descendants of the actors of these two great dramas should meet in an English city in New France! Here the American may forget Yorktown in Louisburg, the Englishman Bunker Hill in Quebec, and the Frenchman both Louisburg and Quebec in Chateauguay ; while we Canadians, English and French, in a forgiving spirit, overlooking your unseemly quarrels, are only too happy to welcome you to our country, this land on which and for which you have so often fought.

Once, and only once, before in the history of the world could such a gathering as this have taken place. Divided though the Greeks were, a Hellenic sentiment of extraordinary strength united them in certain assemblies and festivals. No great flight of imagination is required to picture a notable representation of our profession in the fifth century, B.C., meeting in such a colonial town as Agrigentum under the presidency of Empedocles. Delegates from the mother cities, brilliant predecessors of Hippocrates of the stamp of Damocedes and Herodicus, delegates from the sister colonies of Syracuse and other Sicilian towns, from neighboring Italy, from far distant Massilia, and from still more distant Panticapaeum and Istria. And in such an assemblage there would have been men capable of discussing problems of life and mind more brilliantly than in many subsequent periods, in proportion as the pre-Hippocratic philosophers in things medical had thought more deeply than many of those who came after them.

We English are the Modern Greeks, and we alone have colonized as they did, as free people. There have been other great colonial empires, Phœuician, Roman, Spanish, Dutch and French, but in civil liberty and in intellectual freedom Magna Grocia and Greater Britain stand alone. The parallel so often drawn between them is of particular interest with reference to the similarity between the Greek settlements in Sicily and the English plantrtions on the Atlantic coast. Indeed, Freeman says, "I can never think of America without something suggesting 